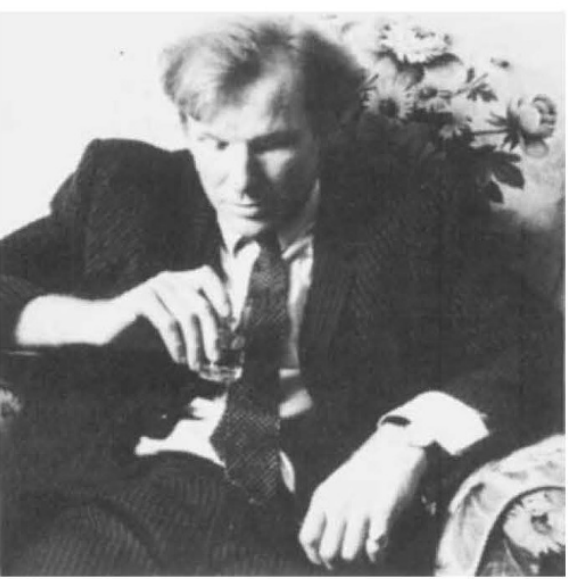

Time to drown your sorrows?

\section{US scientists find carcinogen traces in Scotch whisky}

US scientists have found traces of nitrosamines, one of the most potent known carcinogens, in six brands of Scotch whisky. A few months ago, similar traces were found in various types of beer.

In both cases it appears that the nitrosamines are formed during the drying of sprouted barley malt. The levels detected are small, less than two parts per billion, according to Dr David H. Fine and Dr E. Ulku Goff, who carried out a study as part of a project funded by the National Science Foundation.

However levels as low as 10 parts per billion of nitrosamines are known to increase the incidence of tumours in laboratory animals. The beer industry has already said that, although little is known about the effects of such low doses on humans, it is taking steps to eliminate the presence of nitrosamines. It expects to have a solution "within a matter of months".

A spokesman for the Distilled Spirits Council of the US said last week that there was a marked discrepancy between the results of the NSF study and measurements reported last year by the World Health Organisation in Geneva, which had found nitrosamine levels of less than 0.2 parts per billion in Scotch whiskies. The council said this difference "may raise questions about the accuracy" of the new measurements.

But Dr Lawrence Garfinckel of the American Cancer Society doubted that such small amounts of nitrosamines would cause cancer. The most significant factor for him was that many drinkers were also smokers; a synergistic effect could account for the increased death rate from mouth and throat cancers that had shown up in studies of beer, wine and whisky drinkers.

The brands of Scotch whisky said by the NSF study to contain nitrosamines are: Chivas Regal, Black and White, J \& B, Ballantine's Sandy Scot and Cutty Sark. Nitrosamines were not discovered in White Label whisky, nor in 46 other alcoholic beverages that were also studied.

\title{
Press banned from conference
}

The press is to be excluded from a meeting to evaluate short term, in vitro tests for carcinogenicity, following a ruling by the conference's organising committee. A decision not to invite journalists to attend the October, 1979 meeting in Atlanta, Georgia was taken when some of the participants voiced fears that the attendance of the press at the event would have an inhibitory effect and restrict the usual scientific discussions on such occasions. It has been decided, however, that in view of media interest in the subject, information on the conclusions of the conference will eventually be issued in December, at a press conference to be held in Washington.

Decisions to exclude the press from important scientific meetings are not without precedent. Recently, COGENE, the Committee on Genetic Experimentations of the International Council of Scientific Unions attempted to ban the reporting of the proceedings of a meeting on genetic engineering at Wye College in Kent. (See Nature, 278, 496, 1979). The directive announcing the ban was greeted with a storm of protest and COGENE were forced to reverse their decision. The criticism of a reporting ban could perhaps have been predicted, given the public interest in genetic engineering.

Carcinogens are also a subject which are much in the public eye, a fact given emphasis by the current proposals for their control being discussed by Government Regulatory Authorities in Europe and the United States. European regulatory authorities appear to be far more in favour of in vitro tests as a screening net for carcinogens than do their counterpart organisations in the US. The Environmental Protection Agency, for example, views these tests with some doubt.

\section{Hazards at work 'kill 100,000 a year'}

In a draft report to the President, the Toxic Substances Strategy Committee of the US Council on Environmental Quality claims that "more than 100,000 workers are believed to die each year as a result of physical and chemical hazards at work". The committee estimates that between $20 \%$ and $38 \%$ of all cancer may be caused, in part, by occupational exposure to carcinogens.

The report says prevention is the major key to controlling these environmental hazards and calls for the rigorous application of more than two dozen statutes for the regulation of toxic chemicals already on the books. It also advocated more legislation, including setting up a federal authority responsible for cleaning up hazardous waste sites.

More than 43,000 chemicals are listed by
In view of the importance of the short term tests, and concern about the variability in results reported from different laboratories testing the same chemicals, two scientists - Dr John Ashby of ICI's Central Toxicology Laboratory, Alderley Edge, Cheshire, UK, and Dr F.J. Serres, NIEHS, Research Triangle Park, North Carolina, U.S., decided to organise a carefully controlled study to evaluate short term tests. Ashby, with the resources and expertise of ICI to assist him, was responsible for the synthesis, coding and distribution of some 42 chemicals to be tested by 25 in vitro assays in various laboratories throughout the world (see Nature, 274, 740; 1978). The results of this valuable collaborative programme will be discussed at Atlanta in October.

The one notable ommission in the list of participants in Atlanta is Dr Bruce Ames of the University of California. Ames, who developed the famous in vitro test for carcinogenicity which bears his name declined to take part in the Ashby/Serres study. The Ames test has, however, been evaluated in several laboratories along with other tests.

Few scientists involved with short term tests are unaware of the significance of the Atlanta meeting; Government Regulatory Authorities are similarly aware. Dr David Douglas, Head of the UK Health and Safety Executives unit for collating information on toxic substances referred to the Atlanta meeting as the one which would "take the lid off"' the subject of short term tests.

The importance of the Atlanta meeting cannot be denied. It is this which makes the intended exclusion of journalists so controversial. It remains to be seen whether the organisers will have second thoughts and reverse their decision.

Alastair Hay

the Environmental Protection Agency as being subject to regulation. It may take years to determine whether or not a substance is hazardous and the complexities in reaching such a judgement are enormous. But the committee feels that the difficulties can be mitigated, to some extent, by greater cooperation between agencies involved in toxics-related research. The Government is to spend around $\$ 1$ billion on toxics research next year.

The report has drawn some criticism from the chemical industry. The Chemical Manufacturers Association called it a "hodgepodge of concepts and recommendations that have been either disputed or discredited since the committe was created in 1977." 